\title{
SOCIO-AFFECTIVE STRATEGIES EMPLOYED BY STUDENTS IN SPEAKING CLASS
}

\author{
Maulid Robiansyah; Pryla Rochmahwati \\ Institut Agama Islam Negeri (IAIN) Ponorogo. \\ radenmaulidrobiansyah@gmail.com \\ Pryla@iainponorogo.ac.id
}

\begin{abstract}
This research is aiming at scrutinizing the socio-affective strategies used by students in speaking class at SMP Ma'arif 1 Ponorogo. This research employed qualitative approach, and the design was case study was conducted on the Eighth Grade B class of SMP Ma'arif 1 Ponorogo, and focused on the description of using socio-affective strategies in teaching speaking at the Eighth Grade B class of SMP Ma'arif 1 Ponorogo. The data in this research is collected through interview, observation, reviewing the documents. The data were analyzed by using data Mattew B Miles and Michael Hubberman's view of data reduction, data display and drawing conclusion. The result of this research revealed that (1) the implementation of socio-affective starategies is devided into three activities namely; Pre activities, main activities, and the last activities. In pre activities there are two activities, greeting and apperception. In main activities, teacher applied "socio-affective stratgies. The findings that. In the last activities the teacher gave an evaluation and motivation. In evaluation activity a teaching and learning process need to be evaluated. (2) Those the role of the teacher is as follow in supporting the implementation of socio-affective strategies at Eighth Grade B Class of SMP Maarif 1 Ponorogo is very important because as a teacher holds an important position in the learning process. The roles teachers play in English Language Teaching (ELT) field are mostly of an assessor, organizer, facilitator, prompter, motivator, participant, monitor, model, etc.
\end{abstract}

Keywords: Socio-affective strategies and teaching speaking

\section{INTRODUCTION}

English has four basic language skills. They are speaking, reading, and writing, and listening. Speaking and writing are productive skills. Meantime, listening and reading are included receptive skills. The four skills are learned by the people to make them understand English well. It is taught to develop the students' language qualification. It is learned by the students to communicate.

To communicate well with people around the world, the most important skill to be mastery by the students is speaking. Speaking itself is interpreted as 
ainteractive process of building meaning that involves manufacturing, receiving and cultivating information (Kathleen and David Nunan, 2005;2). It is an important skill to promote human quality in their communication and interaction with others. Speaking can be learned by people to conduct communication directly. It can be used by people to maintain a human relationship. They can use it to convey the purpose of information.

Furthermore, Richards state that the acquisition of speaking skills in English is a priority for many second-language or foreign-language learners. Therefore, learners frequently evaluate their triumph in language learning as well as the effectiveness of their English course on the basis of how much they feel they improved in their language competence (Jack C Richard,2008;19). It means that speaking is an important skill that must be learned in English Foreign Language. Indeed, the students' achievement will be measured by their speaking ability. In other word, they have good achievement it means thatstudents can speak well in English.

Speaking skill is used to transfer information, concepts, explain things, conduct a discussion with other people. and certain people with our stories. So, some information can be taken and shared by people to another communicatively. It is like Willing's perception in Bailey and Nunan's book, communicative learners like talking to a friend in English, listening to native speakers and learning through conversation. Speaking is a complex skill requiring the simultaneous use of different abilities which often develop different rates. It means the mastering of speaking skills needs to be practiced continuously. Speaking needs more time to be mastered by several people since it is not a simple skill. It is needed in every teaching and learning process, to answer questions, to ask questions, to conduct a discussion, to do a presentation, etc. So, language is used continuously as a media for communication in mastering the target language.

Based on the facts gathered from observation at SMP Ma'arif 1 Ponorogo there were some problems with the teaching speaking process in the Eighthgrade B class of SMP Ma'arif 1 Ponorogo. Speaking English was difficult for them, but the teacher did not give much attention to it. They had boring activities in the English class. Many students face some problems dealing with Speaking English. They have difficulties in producing appropriate English utterances and lack self-confidence to speak English. They are embarrassed and not confident to speak English in front of their teacher and friends.They often feel afraid of making a mistake when they speak English. Furthermore according to one of the English teacher the students feel difficult to study in speaking because their self-confident and motivation in speaking is low.

In this case, for every teacher, the most challenging task is to grab a student's attention and effectively convey the message. A teacher should be creative in creating suitable and attractiving activities to help their students improve their oral production since English teachers play important roles to support and to help their students practice English in class. Their prime motive 
is to make sure that the ideas are thoroughly explained to the students. They aim to impact each lesson in such a way that it creates a lasting impression on their minds. Another important aspect that concerns teachers are how to continuously hold the attention of the students throughout a classroom session. Making the teaching-learning process an interesting, entrancing, and beneficial experience is also of prime importance for the teachers. However, the most important point is giving motivation in teaching-learning activity. Motivation is an important aspect that can be lead students to learn successfully. The role of motivation in the learning process is really important to achieve the goals. Without high motivation, learners with good notable abilities can not achieve their goals. In line with this, the use of various language learning strategies to support the teaching and learning process of speaking is important. Language learning strategies vary widely and they are divided into distinct categories. Oxford $(1990 ; 16)$ described language learning strategies are mainly classified as memory, cognitive, compensation, metacognitive, affective, and social strategies.

Socio-affective strategies as a part of language learning strategies separately under the category of indirect language learning strategies. Furthermore, Rubin in Afdalmaujon A Hardan (2013, 1713) defined language learning strategies as behaviors, steps, or techniques that language learners apply to facilitate language learning. Moreover, Ghani $(2013,1715)$ in Afdalmaujon A Hardan defined language learning strategies as specific actions, behaviors, steps, or techniques that students frequently use to improve their progress. In a comprehensive definition, Kahraman defines socio-affective are the mental and physical activities that language learners consciously choose to regulate their emotions and interactions with other people during their language learning process (Kahraman, 2013;2). In more detail, according to O'Malley and Chammot (1990) in Lystiana Nurhayat Hakim and Yuan Suniar $(2019 ; 128)$ define socio-affective strategies as strategies that help learners regulate and control emotions, motivations, and attitudes toward learning, as well as help learners, learn through contact and interaction with others.

Furthermore, to support this research, there are some previous research which have shown the implemented of socio-affective strategies. First, the journal is made by (Lystiana Nurhayat Hakim and Yuan Suniar, 2019) which has the title Socio-Affective Strategies in Enhancing Students' Speaking Motivation. The objective of this research is to solve the students' problems and enhance their speaking ability. a teacher has to be able to use languagelearning strategies especially socio-affective strategies that can involve students in practicing speaking and give motivation. The study utilized qualitative research. The finding of the study indicated that the implementation of the socio-affective strategies was successful in improving the students' speaking ability since the criteria of success were achieved. They assume that using socio-affective strategies can improve Speaking mastery. From their 
research can be concluded that there was an influence of the use of socioaffective strategies in teaching speaking.

Second, previous research from a journal made by (Afrina, 2015) which has a title Socio Affective Strategies Used in Speaking III by The English Department Students of STAIN Batusungkar. The Objectives of the study are to find out whether there is an improvement in students' speaking skills by using socio-affective strategies. In conducting the research, the writer applied qualitative research design as the research methodology. From her research can be concluded that there was an influence of the use of socio-affective strategies in teaching speaking. It is can be seen They thought that socioaffective strategies helped them to enhance their motivation and confidence in speaking.

Third, the previous research from a journal is made by (Siamak Zeynali, Simin Zeynali, Seyyed Fariborz Pishdadi Motlagh, 2015) which has a title The Effects of Socio Affective Strategy in the Enhancement of Reading Comprehension among Iranian EFL Learners. This study adopted quasi-experimental design with proficiency test to find the homogeneity of groups. The objective of this research is to investigate the effects of socio-affective strategies in the enhancement of reading comprehension in Iranian EFL learners and also the present study aimed to determine the relationship between socio/affective strategy and reading comprehension in Iranian intermediate EFL learners. From their research, the researcher concludes that there are outcomes that show that using socio-affective strategies was a more helpful factor for learners to answer reading comprehension questions. Departing from the problems above, the researcher intends to know the implementation of socio-affective strategies used in their class, under the title "Socio-Affective Strategies Used by Students in Speaking Class at SMP Ma'arif 1 Ponorogo. This research interest on (1) how students employed socio-affective strategies?, (2) How is the role of the teacher in supporting the Socio-Affective Strategies used by students in speaking class at SMP Ma'arif 1 Ponorogo?.

\section{METHODS}

In this research, qualitative study was used as the first model as the approach. Additionally, Kothari $(2004 ; 3)$ states that the qualitative research is concerned with qualitative phenomena relating to or enclosing quality or kind. Besides that, Mackey and Gass $(2005 ; 162)$ explain in brief the definition that qualitative research can be taken to refer to research that is based on descriptive data that does not make (regular) use of statistical procedures. Qualitative research is conducted through intense or prolonged contact with a field or life situation. These situations are typically banal or normal ones, reflective of the everyday life of individuals, groups, societies, and organizations. Mattew B Miller and Michael Hubertman $(1994 ; 6)$ state that the researcher attempts to capture on the perceptions of local actors from the inside, through a process of deep attentiveness, of 
empathetic understanding and of suspending or bracketing preconceptions about the topic under discussion. The data of this research were conducted through observation, interview, and documentation. The research procedure of this research is formulated as follows : Planning, aplication, and reporting.

The additional case study as the research design. Yin (2003;13) defines a case study as "A case study is an empirical inquiry that investigates a contemporary phenomenon (the 'case') within its real-life context, especially when the boundaries between phenomenon and context may not clearly evident". The researcher employed the case study research to describe the teaching speaking using socioaffective strategies at SMP Ma'arif 1 Ponorogo.

\section{FINDINGS AND DISCUSSIONS}

\section{The Socio-Affective Strategies Employed by Students}

Teaching is a process of transferring knowledge between teachers and students in the teaching environment (school). A teacher needs a method or strategy to create effective teaching speaking. To make the students understand the material easily, the teacher must have an appropriate method or strategies. The English teacher in SMP Ma'arif 1 Ponorogo used socio-affective strategies in teaching students' speaking skills.

The socio-affective strategies encourage students' belief with their own/develop their self-confidence when they should speak in front of the class. Furthermore, Habte-Gabr (2006) in Lystiana Nurhayat Hakim and Yuan Yuniar $(2019 ; 128)$, proposed that socio-affective strategies are strategies that using feelings in the teaching-learning process include empathy between the learners and the instructors to build a positive effect because the relationship between of them is important. They also state that socio-affective strategies are the most stated effective strategies to increase student's learning.

In using socio-affective strategies, the students have several strategies. This research involves six strategies for the students. Based on the data analysis on the previous part, there were several findings that were found in relation to students' socio-affective strategies. The first strategy for the students in socio-affective strategies was asking question. In the class, the students were demanded to ask each other and their teachers for clarification and correction to increase their speaking. Based on the data analysis of the observation and interview, it was supported that they did strategies of asking questions because they asked clarification and correction. Furthermore, when they speak in the front of the class when on the group work, they did consider the vocabulary that they were going to speak. If they did not know the pronunciation of the vocabulary, they asked clarification and correction from their friends. Based on the data analysis, it can be concluded that the students used asking questions about clarification and correction with the teachers and their friends. Furthermore, Oxford $(1990 ; 145)$ said that asking questions helps students get closer to the intended meaning and thus aids their understanding. 
The second strategy for the students in socio-affective strategies was cooperating with others. Based on the data analysis, it was found that the students used strategy of cooperating with others. In cooperating with others, the students were demanded to cooperate with their friends. From the data analysis, the students did cooperate with others, but they did not cooperate with proficient users. Based on the data observation and interview, it was supported that the students applied cooperating with others especially with their friends or peers and did not applied cooperate with proficient users. The strategy of cooperating with others is a good opportunity for the students to develop their English proficiency if they can train themselves to practice English language. Furthermore, Oxford $(1990 ; 146)$ said that cooperative learning consistently shows the following significant effects: increase confidence and enjoyment, greater and more rapid achievement, more respect for the teacher, stronger language learning motivation, and more language practice opportunities.

The third strategy for the students in socio-affective strategies was empathizing with others. In empathizing with others, the students was apply this strategy. Based on the observation and interview, it was supported that the students applied empathizing with others successfully. For examples, in the main activity, when their friends can notunderstood, their friends who more understood gave the explanation in the simple ways. However, social strategies, can help all students increase their abilityto empathize by developing cultural understanding and becoming aware of others' thoughts and feelings (Oxford, 1990;146).

The fourth strategy for the student in socio affective strategies was encouraging yourself. In the class, The teachers used encouraging yourself strategy such as making positive statement and rewarding yourself. For the examples, the teachers gave some motivation and always appreciate the efforts of their students by giving awards like applause, etc. This strategy that the teacher applied was suitable with the effective ways in teaching speaking class. This strategy traying to give a description of being a teacher is not just limited to providing knowledge but to be a figure who provides motivation to their students.

From four strategy of socio-affective strategies that the teacher applied ,these strategies were employed in the speaking class. This strategies very effective used at speaking class. Furthermore, Oxford $(1990 ; 135)$ said that that affective strategies help to regulate emotions, motivation, and attitudes. Meanwhile, social strategies help students learn through interaction with others. Besides, O'Malley and Chamot (1990) in LystianaNurhayat Hakim and Yuan Suniar $(2019 ; 128)$ proposed that socioaffective strategies helps the learners regulate and control emotions, motivations, and attitudes toward learning, as well as learners learn through contact and interaction with others. In addition, researcher fined 
that these all the characteristic of socio-affective strategies. Those characters are as follow:

a. Focused on cause to emerge cultural understanding and becoming aware of others' thoughts and feelings.

b. Permitstudents to become more self-directed.

c. Are flexible.

d. Assist to the main goal, communicative competence.

e. It requires group cooperation and interaction.

f. Concentration to the lesson.

Those all are how socio-affective strategies method implemented in building students' speaking skills at $8^{\text {th }}$ Grade B Class students of SMP Ma'arif 1 Ponorogo.

\section{The Role of the Teacher in Supporting Socio-Affective Strategies Used by Students}

As one of the educational activities, teaching speaking holds an important role that must be conducted truly, therefore the role of the teacher is very important. English Foreign Language (EFL) teachers play the greatest role in developing students'speaking skills. Jeremy Harmer $(2007 ; 107)$ said that a teacher is like a gardener because he/she plants the seeds and watches them grow. Students are the field and the seed is seen as the knowledge planted by educators. As gardeners take very good care of the flowers of the rose, water them when necessary, the teacher also plays different roles in the lives of the students not only by planting knowledge in them but also acting as a model in the classroom and outside it with their personal lives.

Furthermore, Vilar in Salcuk Koran $(2015 ; 407)$ proposed that teachers have two primary functions in education: the managerial and the instructional functions. The latter refers to the conditions that teachers create for learning to take place and the other is the knowledge that the teachers impart in the classrooms. Teachers should undertake these functions synchronously for streamlined language instruction because they can not be separated.

In English Language Teaching classes teachers are expected to teach effectively, to guide students and to keep order in the classroom. Furthermore, Leu (2005) in Salcuk Koran (2015;407) state that the most crucial role teachers are expected to play in providing and maintaining a good quality of education. To achieve this quality, teachers should be promoted to use their energy, knowledge along with motivation. Thus, teachers should play various roles according to the skills and needs of the learners. The roles teachers play in English Language Teaching (ELT) field are mostly of an assessor, organizer, facilitator, prompter, motivator, participant, monitor, model, etc. Furthermore, according to Jeremy Harmer (2001;275-276), There are three important roles that teachers can play if 
they want to get their learners to speak fluently. There are prompter, participant, and feedback provider.

On the other hand, based on the observation and interview with the teachers and students at Eighth Grade B Class of SMP Ma'arif 1 Ponorogo, the researcher found that in the Eight Grade B class, the teacher always played the role as a teacher. For the examples during the speaking tasks, the teachers always gave some motivation to their students in the preactivity and the last activity. Then, the teacher always takes as a model, monitor, facilitator, assessor when the main activity goes on. Then, the teacher gives feedback after the oral activity. One more role is that of the participant. In this activity, when the teacher participates in discussions not as teachers but as peers of language learning. The teacher usually assigns students to perform a speaking activity and from time to time intervenes to give feedback or corrects mistakes only when necessary. Based on the explanation above, it was known that the role of a teacher in supporting the implementation of socio-affective strategies at Eighth Grade B Class of SMP Ma'arif 1 Ponorogo is very important because as a teacher holds an important position in the learning process.

\section{CONCLUSION}

The researcher conclude that the implementation of using socioaffective strategies, the teacher applied 6 strategies such as askig question, cooperating with other, empathizing with other, reducing students' anxiety, encouraging them to speak, and controlling their emotional.The students also have positive mindset or perception toward used socio-affective strategies in teaching speaking at Eighth Grade B Class at SMP Ma'arif 1 Ponorogo. And, Those the role of the teacher is as follow in supporting the implementation of socio-affective strategies at Eighth Grade B Class of SMP Maarif 1 Ponorogo is very important because as a teacher holds an important position in the learning process. The roles teachers play in English Language Teaching (ELT) field are mostly of an assessor, organizer, facilitator, prompter, motivator, participant, monitor, model, etc

\section{REFERENCES}

Afriana. Socio Affective Strategies Used in Speaking III by The English Department Students of STAINBatusungkar. Journal Basis,Vol.3,1,2015. http://ejournal.upbatam.ac.id/index.php/basis/article/view/428(Accesse d 20 August 2019).

Hakim, LystianaNurhayat and Yuan Suniar. 2019. Socio-Affective Strategies in Enhancing Students' Speaking Motivation., Jurnal Basis, Vol. 6No.1.http://ejournal.upbatam.ac.id/index.php/basis/article/view/428 (Accessed 20 August 2019). 
Hardan, Afdalmaujon A. 2013. Language Learning Strategies : General Overview, procedia Social and Behavioral Sciences, 4th International Conference on New Horizons in Education, 106. (Accessed24 August 2019).

Harmer, Jeremy. How to Teach English. England: Longman, 1998.

Kahraman. F,G.The Effective of Socio-Affective Language Learning Strategies and Emotional Intelligence Training on English as a Foreign Language (EFL) Learners' Foreign Language Anxiety in Speaking Classes.BilkentUniversity, 2013. http://www.thesis.bilkent.edu.tr/0006387.pdf, (Accessed 20 August 2019).

Koran, Selcuk. The Role of Teacher in Developing learners' Speaking Skill, ResearchGate(online),

https://www.researchgatenet/publication/322112785, (Accessed 9 April 2020).

Kothari, C.R. Research Methodology: Methods and Techniques (Second Revised Edition) New Delhi: New Age International Publishers, 2004.

Mackey, Alison, Susan M. Gass. Second Language Research: Methodology and Design. London: Erlbaum Associates Publishers, 2005.

Miller, Mattew B. An Expanded Sourcebook Qualitative Data Analysis: Second Edition. United States of America: SAGE Publications, 1994.

M. Bailey, Kathleen and David Nunan (Series Editor). Practical English Language Teaching Speaking. Boston: Mc Graw Hill, 2005.

Richard, Jack, C and Rodgers. Teaching Listening and Speaking, from Theory to Practice, New York : Cambridge University Press, 2008.

Samida, Deepak K, 2013. Language Learning Strategies. Major English Paper (online), https://www.ugc.ac.in/mrp/paper/MRP-MAJOR-ENGL-201318577-PAPER.pdf, (Accessed 20 August 2019).

Oxford, Rebecca L. Language Learning Strategies : What Every Teacher Should to Know. Boston: University of Alabama, 1990.

Yin, R.K. Case Study Research: Design and Methods (3rd ed.) Thousand Oaks, California: Sage, 2003.

Zeynali, Siamak, Simin Zeynali, Seyyed Fariborz Pishdadi Motlagh. 2015. The Effects of Socio Affective Strategy in the Enhancement of Reading Comprehension among Iranian EFL Learners, International Journal of Language and Linguistics, 4 (2-1):9-22, University of Tabriz, Iran. https://www.academia.edu/31665578/International Journal of Language and Linguistics The Effects of Socio Strategy in the Enhancement of Re ading Comprehension among Iranian EFL Learners, (Accessed 20 August 2019). 